\title{
Pengaruh Direksi Wanita terhadap Kualitas Laporan Keuangan yang Dimoderasi oleh Efektivitas Komite Audit
} \author{
Bandung, Indonesia. \\ *novitanurulk@gmail.com, edi66sukarmanto@gmail.com, \\ mey.maemunah620@gmail.com
}

Novita Nurul Kamila*, Edi Sukarmanto, Mey Maemunah

Prodi Akuntansi, Fakultas Ekonomi dan Bisnis, Universitas Islam

\begin{abstract}
This study aims to examine the influence of female directors on the quality of financial statements, and add audit committee effectiveness as moderating variables. The research objects used in this study were female directors, the audit committee's effectiveness, and the quality of financial reports. The subjects in this study were manufacturing companies listed on the Indonesia Stock Exchange (IDX). The research method used is verification with a quantitative approach. This study uses secondary data with a sample of 91 manufacturing companies listed on the Indonesia Stock Exchange (IDX) for the 2016-2020 observation period or 455 observational data. Hypothesis testing in this study used multiple linier regression analysis and moderating regression analysis. The test results show that female directors significantly affect the quality of financial reports. The increasing number of female directors will improve the quality of good financial reports. The audit committee's effectiveness has a significant effect on the quality of financial statements. Increasing the audit committee's effectiveness will improve the quality of good financial reports. In addition, this study also shows that the audit committee's effectiveness as a moderating variable can strengthen the influence of female directors on the quality of financial reports. It is recommended for further research to be able to research in other sectors or increase the period of the research.
\end{abstract}

Keywords: Female Directors, Audit Committee's Effectiveness, Quality of Financial Reports.

\begin{abstract}
Abstrak. Penelitian ini bertujuan untuk mengetahui pengaruh direksi wanita terhadap kualitas laporan keuangan yang dimoderasi oleh efektivitas komite audit. Objek penelitian yang digunakan dalam penelitian ini adalah direksi wanita, efektivitas komite audit, dan kualitas laporan keuangan. Subjek dalam penelitian ini adalah perusahaan manufaktur yang terdaftar di Bursa Efek Indonesia (BEI). Metode penelitian yang di gunakan adalah verifikatif dengan pendekatan kuantitatif. Penelitian ini menggunakan data sekunder dengan sampel sebanyak 91 perusahaan manufaktur yang terdaftar di Bursa Efek Indonesia (BEI) untuk rentang waktu pengamatan 2016-2020 at au 455 data pengamatan. Pengujian hipotesis dalam penelitian ini menggunak an analisis regresi linier berganda dan analisis regresi pemoderasi. Hasil pengujian menunjukkan bahwa direksi wanita berpengaruh secara signifikan terhadap kualitas laporan keuangan. Semakin meningkat direksi wanita maka akan meningkatkan kualitas laporan keuangan yang baik. Efektivitas komite audit berpengaruh signifikan terhadap kualitas laporan keuangan. Meningkatny a efektivitas komite audit maka akan meningkatkan kualitas laporan keuangan yang baik. Selain itu, dalam penelitian ini juga menunjukkan bahwa efektivitas komite audit sebagai variabel pemoderasi dapat memperkuat pengaruh antara direksi wanita terhadap kualitas laporan keuangan. Disarankan untuk penelitian selanjutnya dapat meneliti pada sektor lain at au menambah rentang waktu pengamatan.
\end{abstract}

Kata Kunci: Direksi Wanita, Efektivitas Komite Audit, Kualitas Laporan Keuangan. 


\section{A. Pendahuluan}

Laporan keuangan merupakan sebuah informasi yang mencerminkan posisikeuangan dan mencerminkan juga kinerja suatu perusahaan pada periode tertentu yang dipergunakan untuk pengambilan keputusan oleh para pihak internal maupun pihak eksternal perusahaan. Agar laporan keuangan dapat berguna bagi pemakai maka diperlukan kualitas laporan keuangan yang baik. Terdapat fenomena yang terjadi yaitu terdapat dua komisaris yang tidak mau menandatangani laporan keuangan PT Garuda Indonesia tahun 2018. Hal tersebut karena melanggar PSAK No.23, sehingga laporan keuangan yang disajikan tersebut tidak dapat digunakan sebagai dasar untuk pengambilan keputusan karena diduga adanya praktik manipulasi (1).

Selanjutnya, terdapat kasus yang terjadi dimana BEI (Bursa Efek Indonesia) mempertanyakan terkait angka-angka keuangan anak perusahaan PT Envy Technologies Indonesia Tbk yaitu Ritel Global Solusi yang dikonsolidasikan ke dalam laporan keuangan tahun 2019 mengingat Ritel Global Solusi disebutkan tidak menyusun laporan keuangan pada tahun tersebut, sehingga diduga adanya unsur manipulasi. Laporan keuangan konsolidasi tersebut juga sudah memperoleh persetujuan dari direksi perusahaan yang menjabat dan bertanggung jawab atas laporan keuangan pada periode tersebut di mana terdapat direksi wanita dalam susunan dewan direksinya (2). Kasus tersebut mencerminkan bahwa kualitas laporan keuangan yang dihasilkan oleh perusahaan tersebut dinilai memiliki kualitas rendah karena terdapat unsur manipulasi di mana penyajiannya tidak representasi tepat atau penyajian jujur.

Kualitas laporan keuangan yang baik menurut IAI (3) perlu memiliki karakteristik kualitatif fundamental meliputi karakteristik relevan dan penyajian jujur. Kegunaan informasi keuangan juga dapat ditingkatkan jika informasi tersebut dapat comparable, verifiable, timely, dan understandable. Menurut Kingsley (4), "informasi laporan keuangan seharusnya tidak mengandung kesalahan material dan bias, serta tidak menyesatkan para pengguna laporan keuangan tersebut". Untuk itu, laporan keuangan dikatakan berkualitas baik jika informasi yang disediakan tidak mengandung unsur kesalahan maupun kecurangan yang bersifat material.

Salah satu pihak yang mempunyai tanggungjawab dalam penyusunan dan penyajian laporan keuangan ialah direksi. Menurut Zakarsyi (5) "direksi adalah sekelompok individu yang dipilih untuk bertindak sebagai perwakilan para pemegang saham untuk membangun aturan yang terkait dengan manajemen perusahaan dan membuat berbagai keputusan penting perusahaan". Keberagaman dewan direksi yang beragam gender dapat memantau dan mengontrol kegiatan manajemen dengan lebih baik karena adanya berbagai sudut pandang (6). Hal tersebut karena wanita cenderung memiliki sifat kehati-hatian dalam mengambil keputusan. Seperti menurut Thian (7) menyebutkan bahwa "wanita cenderung melakukan perenungan dan menganalisis masalah-masalah secara mendetail sebelum mengambil keputusan, serta mengolah keputusan yang telah diambil".

Berdasarkan penelitian yang telah dilakukan oleh Srinidhi (8), perempuan lebih independen dalam pengambilan keputusan, kurang toleran terhadap perilaku tidak etis dan mereka mengambil risiko yang rendah. Keberadaan Direksi Wanita membuat proses pemantauan menjadi lebih baik termasuk kualitas laporan keuangan. Keberagaman gender dalam susunana Dewan Direksi juga menurut Post (9) dapat meningkatkan jenis pengetahuan, ide, dan perspektif yang dapat dipertimbangkan dalam pengambilan keputusan. Hal ini dapat meningkatkan efektivitas dari pemantauan dan kualitas laporan keuangan yang baik. Direktur wanita secara signifikan membatasi praktik manajemen laba (10).

Untuk meningkatkan pengawasan terhadap kualitas laporan keuangan agar menghasilkan kualitas yang baik maka dibutuhkan efektivitas Komite Audit. Komite Audit ialah bagian dari dewan komisaris yang bertanggung jawab dalam mengawasi proses pelaporan keuangan. Seperti menurut OJK (11) "komite Audit memiliki tugas dan tanggung jawab salah satunya untuk melakukan penelaahan atas informasi keuangan yang akan dikeluarkan perusahaan kepada publik dan/atau pihak otoritas antara lain laporan keuangan, proyeksi, dan laporan lainnya terkait dengan informasi keuangan perusahaan". Agar dapat mempublikasikan laporan keuangan yang berkualitas, Komite Audit harus meningkatkan pengawasan dan keefektifannya dalam menjalankan tugas. Menurut Hery (12), efektivitas Komite Audit sebagai 
pihak independen, melalui pengawasannya atas pelaporan keuangan dapat mengurangi kemungkinan dilakukannya tindakan manajemen laba yang berlebihan. Untuk itu, efektivitas Komite Audit harus ditingkatkan agar dapat menghasilkan kualitas laporan keuangan yang baik.

Penelitian terdahulu menunjukkan bahwa efektivitas Komite Audit dalam memenuhi tanggung jawabnya perlu memastikan efisiensi dari auditor internal dan pengendalian internal, independensi auditor eksternal, dan keandalan pelaporan keuangan (13). Berbeda dengan penelitian sebelumnya, penelitian Mouratidou (14) menunjukkan bahwa, efektivitas Komite Audit yang berkarakteristik frekuensi rapat, independensi, keahlian keuangan Komite Audit, dan jumlah Komite Audit tidak dapat menjamin bahwa kualitas laporan keuangan yang dihasilkan oleh perusahaan baik. Ketidakkonsistenan hasil penelitian di atas menarik untuk diteliti kembali. Tetapi, yang memberikan perbedaan penelitian ini dengan penelitian sebelumnya ialah variabel independen yang digunakan yaitu direksi wanita dan efektivitas komite audit dan penambahan tahun penelitian.

Berdasarkan latar belakang masalah yang telah dipaparkan sebelumnya, permasalahan dalam penelitian inidapat diidentifikasikan dalam bentuk pertanyaan sebagai berikut:

1. Apakah direksi wanita berpengaruh terhadap kualitas laporan keuangan?

2. Apakah efektivitas Komite Audit berpengaruh terhadap kualitas laporan keuangan?

3. Apakah direksi wanita berpengaruh terhadap kualitas laporan keuangan dimoderasi oleh efektivitas Komite Audit?

Selanjutnya berdasarkan identifikasi masalah di atas, maka tujuan dilakukannya penelitian ini ialah sebagai berikut:

1. Untuk mengetahui pengaruh direksi wanita terhadap kualitas laporan keuangan.

2. Untuk mengetahui pengaruh efektivitas Komite Audit terhadap kualitas laporan keuangan.

3. Untuk mengetahui pengaruh direksi wanita terhadap kualitas laporan keuangan dimoderasi oleh efektivitas Komite Audit.

\section{B. Metodologi Penelitian}

Penelitian menggunakan metode penelitian verifikatif dengan pendekatan kuantitatif. Populasi dalam penelitian ialah sebanyak 140 perusahaan manufaktur yang listing di BEI.

Teknik pengambilam sample yang digunakan dalam penelitian yaitu nonprobability sampling dengan purposive sampling yang menghasilkan sebanyak 91 perusahaan manufaktur atau 455 data pengamatan. Selain itu, pengujian hipotesis yang digunakan dalam penelitian ini ialah Uji Asumsi Klasik, Uji Simultan (Uji F), Uji Parsial (Uji t), Uji Regresi Linier Berganda, Moderating Regression Analysis (MRA), dan Koefisien Determinasi $\left(\mathrm{R}^{2}\right)$.

\section{Hasil Penelitian dan Pembahas an}

Darihasilpengujian yang telah dilakukan dengan menggunakan aplikasi SPSS versi 23, diperoleh hasil sebagai berikut:

Tabel 1. RegresiLinier Berganda tanpa Pemoderasi

Coefficients $^{\mathbf{a}}$

\begin{tabular}{|c|c|c|c|c|c|c|}
\hline \multirow{2}{*}{\multicolumn{2}{|c|}{ Model }} & \multicolumn{2}{|c|}{$\begin{array}{l}\text { Unstandardized } \\
\text { Coefficients }\end{array}$} & \multirow{2}{*}{$\begin{array}{c}\begin{array}{c}\text { Standardized } \\
\text { Coefficients }\end{array} \\
\text { Beta } \\
\end{array}$} & \multirow[b]{2}{*}{$\mathrm{t}$} & \multirow[b]{2}{*}{ Sig. } \\
\hline & & B & Std. Error & & & \\
\hline \multirow[t]{3}{*}{1} & (Constant) & -4.474 & .502 & & -8.917 & .000 \\
\hline & DWN & -2.025 & .209 & -.350 & -9.683 & .000 \\
\hline & EKA & -7.583 & .558 & -.490 & -13.586 & .000 \\
\hline
\end{tabular}

Sumber: Data Penelitian yang Sudah Diolah, 2021

Berdasarkan Tabel 1 di atas, dapat diketahui persamaan regresi linier berganda untuk data penelitian yang digunakan ialah sebagai berikut: 


\section{KLK = - 4.474 - 2.025 DWN - 7.583 EKA + $\varepsilon$} berikut:

Dari hasil persamaan regresi linier berganda di atas, dapat diinterpretasikan sebagai

1. Nilai konstanta (a) sebesar -4.474 artinya, nilai konstanta (a) sebesar -4.474 menunjukkan rata-rata M-Score dari Kualitas Laporan Keuangan (KLK) jika Direksi Wanita (DWN) dan Efektivitas Komite Audit (EKA) dianggap tetap atau nol (0).

2. Nilai koefisiensi regresi variabel yang sebesar -2.025 artinya, apabila Direksi Wanita menurun dan variabel lainnya konstan maka nilai M-score pada kualitas laporan keuangan akan meningkat, sehingga kualitas laporan keuangan akan semakin buruk karena semakin terindikasi unsur manipulasi. Hal tersebut karena apabila nilai M-score $>-2.22$ maka akan semakin terindikasi kecurangan. Dapat dikatakan juga apabila Direksi Wanita mengalami peningkatan maka, nilai $\mathrm{M}$-score pada kualitas laporan keuangan akan menurun sebesar -2.025. Semakin menurun nilai M-Score ( $\leq-2.22)$ maka kualitas laporan keuangan akan semakin baik karena semakin tidak terindikasi kecurangan.

3. Nilai koefisiensi regresi variabel yang sebesar -7.583 artinya, nilai koefisien regresi Efektivitas Komite Audit sebesar-7.583 menunjukkan bahwa apabila efektivitas Komite Audit menurun dan variabel lainnya konstan maka nilai M-score pada kualitas laporan keuangan akan meningkat, sehingga kualitas laporan keuangan akan semakin terindikasi kecurangan. Hal tersebut karena apabila nilai M-score > -2.22 maka akan semakin terindikasi kecurangan. Sedangkan meningkatknya efektivitas komite audit, maka nilai M-score pada kualitas laporan keuangan akan semakin menurun sebesar -7.583. Menurunnya nilai M-Score ( $\leq-2.22)$ maka kualitas laporan keuangan pada perusahaan akan semakin baik karena semakin tidak terindikasi kecurangan.

Tabel 2. Regresi Linier Berganda dengan Variabel Moderasi

Coefficients $^{\mathrm{a}}$

\begin{tabular}{|c|c|c|c|c|c|}
\hline \multirow[b]{2}{*}{ Model } & \multicolumn{2}{|c|}{$\begin{array}{l}\text { Unstandardized } \\
\text { Coefficients }\end{array}$} & \multirow{2}{*}{$\begin{array}{c}\text { Standardized } \\
\text { Coefficients }\end{array}$} & \multirow[b]{2}{*}{$\mathrm{t}$} & \multirow[b]{2}{*}{ Sig. } \\
\hline & $\mathrm{B}$ & Std. Error & & & \\
\hline 1 (Constant) & -.899 & .481 & & -1.868 & .062 \\
\hline DWN & -2.599 & .361 & -.231 & -7.193 & .000 \\
\hline EKA & -3.500 & .539 & -.226 & -6.490 & .000 \\
\hline DWN.EKA & -6.333 & .435 & -.530 & -5.566 & .000 \\
\hline
\end{tabular}

a. Dependent Variable: KLK

Sumber: Output Pengolahan SPSS versi 23, 2021

Berdasarkan hasil yang ditunjukkan Tabel 2 di atas, dapat diketahui hasil dari persamaan regresi linier berganda dengan variabel moderasi dalam penelitian ini ialah sebagai berikut:

\section{KLK = - 0.899 - 2.599 DWN - 3.500 EKA - 6.333 DWN*EKA + $\varepsilon$}

Darihasil persamaan regresi linier berganda dengan variabel pemoderasi, masingmasing variabel dapat diinterpretasikan sebagai berikut:

1. Nilai konstanta (a) sebesar -0.899 artinya, nilai konstanta $(\alpha)$ sebesar -0.899 menunjukkan rata-rata M-Score dari Kualitas Laporan Keuangan (KLK) jika Direksi Wanita (DWN), Efektivitas Komite Audit (EKA), dan pemoderasi (DWN*EKA) dianggap tetap atau nol (0).

2. Nilai koefisiensi regresiDireksi Wanita sebesar -2.599 menunjukkan bahwa menurunnya Direksi Wanita dan variabel lainnya tetap, maka akan meningkatkan nilai M-score pada laporan keuangan, yang mencerminkan semakin terindikasi terjadinya manipulasi dalam laporan keuangan.

3. Nilai koefisiensi regresi efektivitas komite audit sebesar -3.500 meunjukkan bahwa menurunnya efektivitas komite audit maka akan meningkatkan nilai M-score pada 
kualitas laporan keuangan, sehingga kualitas laporan keuangan akan semakin buruk karena terdapat unsur manipulasi.

4. Nilai koefisiensi regresi Direksi Wanita yang dimoderasi oleh efektivitas komite audit sebesar -6.333 menunjukkan bahwa menurunnya Direksi Wanita yang dimoderasi oleh efektivitas komite audit sebesar -6.333 maka akan meningkatkan nilai M-score pada kualitas laporan keuangan, sehingga kualitas laporan keuangan akan semakin buruk karena terdapat unsur manipulasi. Hal tersebut karena apabila nilai M-score > -2.22 maka akan semakin terindikasi kecurangan. Sedangkan, apabila Direksi Wanita yang dimoderasi oleh efektivitas komite audit meningkat maka akan menurunkan nilai Mscore pada kualitas laporan keuangan sebesar -6.333 yang menunjukkan bahwa kualitas laporan keuangan tidak terindikasi kecurangan. Hal ini mencerminkan bahwa semakin meningkatnya Direksi Wanita yang dimoderasi oleh efektivitas komite audit maka akan meningkatkan kualitas laporan keuangan yang baik di perusahaan manufaktur yang terdaftar di Bursa Efek Indonesia pada tahun 2018-2020.

Tabel 3. Uji Simultan (Uji F) Model Regresi tanpa Pemoderasi

\begin{tabular}{|l|l|r|r|r|r|c|}
\hline \multicolumn{7}{|c|}{ ANOVA $^{\mathbf{a}}$} \\
\hline \multicolumn{2}{|l|}{ Model } & Sum of Squares & Df & Mean Square & F & Sig. \\
\hline \multirow{3}{*}{1} & Regression & 166.640 & 2 & 83.320 & 209.775 & $.000^{\mathrm{b}}$ \\
\cline { 2 - 8 } & Residual & 179.529 & 452 & .397 & & \\
\cline { 2 - 8 } & Total & 346.169 & 454 & & & \\
\hline
\end{tabular}

a. Dependent Variable: KLK

b. Predictors: (Constant), EKA, DWN

Sumber: Output Pengolahan SPSS versi 23, 2021

Berdasarkan Tabel 3, diperoleh nilai signifikansi dari model regresi berganda tanpa variabel moderasi ialah sebesar 0.000 . Hal tersebut mencerminkan bahwa persamaan regresi dapat digunakan untuk menguji variabel direksi wanita dan efektivitas komite audit terhadap kualitas laporan keuangan. Hal ini dikarenakan nilai signifikansinya lebih kecil dari 0,05. Oleh karena itu, dalam model ini bahwa $\mathrm{H}_{0}$ ditolak dan $\mathrm{H}_{\mathrm{a}}$ diterima atau signifikan, sehingga dapat dilanjutkan untuk pengujian berikutnya.

Tabel 4. Uji Simultan (Uji F) Model Regresi dengan Pemoderasi

\begin{tabular}{|c|l|r|r|r|r|c|}
\hline \multicolumn{7}{|c|}{ ANOVA $^{\mathbf{a}}$} \\
\hline \multicolumn{2}{|l|}{ Model } & Sum of Squares & \multicolumn{1}{c|}{ Df } & Mean Square & F & Sig. \\
\hline \multirow{2}{*}{1} & Regression & 224.078 & 3 & 74.693 & 275.912 & $.000^{\mathrm{b}}$ \\
\cline { 2 - 8 } & Residual & 122.091 & 451 & .271 & & \\
\cline { 2 - 8 } & Total & 346.169 & 454 & & & \\
\hline
\end{tabular}

a. Dependent Variable: KLK

b. Predictors: (Constant), EKA, DWN

Sumber: Output Pengolahan SPSS versi 23, 2021

Tabel 4 menunjukkan bahwa nilai signifikansi model regresi dengan menggunakan variabel moderat $\mathrm{r}$ adalah 0,000 . Hal ini mencerminkan kemampuan menggunakan model regresi untuk menguji variabel direktur wanita yang dimoderasi oleh efektivitas komite audit terhadap kualitas laporan keuangan karena memiliki nilai signifikansi dibawah 0.05. Untuk itu, model ini sesuai dengan kriteria pengujian hipotesis signifikan, sehingga dapat dilanjutkan untuk pengujian berikutnya. 
Tabel 5. Uji Parsial (Uji t) Model Regresi Berganda tanpa Pemoderasi

Coefficients $^{\mathrm{a}}$

\begin{tabular}{|c|c|c|c|c|c|c|}
\hline \multirow{2}{*}{\multicolumn{2}{|c|}{ Model }} & \multicolumn{2}{|c|}{$\begin{array}{l}\text { Unstandardized } \\
\text { Coefficients }\end{array}$} & \multirow{2}{*}{$\begin{array}{c}\text { Standardized } \\
\text { Coefficients }\end{array}$} & \multirow{3}{*}{$\frac{\mathrm{t}}{8017}$} & \multirow[b]{2}{*}{ Sig. } \\
\hline & & B & Std. Error & & & \\
\hline \multirow[t]{3}{*}{1} & (Constant) & -4.474 & .502 & & & .000 \\
\hline & DWN & -2.025 & .209 & -.350 & -9.683 & .000 \\
\hline & EKA & -7.583 & .558 & -.490 & -13.586 & .000 \\
\hline
\end{tabular}

a. Dependen variable: KLK

Sumber: Data Penelitian yang Sudah Diolah, 2021

\section{Pengaruh Dire ksi Wanita te rhadap Kualitas Laporan Ke uangan}

Hasil pengujian pada Tabel 5 menunjukkan bahwa direktur wanita memiliki pengaruh yang signifikan terhadap kualitas pelaporan keuangan, karena tingkat signifikansi untuk direktur wanita adalah 0.000 , lebih kecil dari tingkat alpha $(\alpha)$ yaitu 0.05 . Selain itu, arah koefisiensi yang ditunjukkan pada "B" dalam Unstandardized Coefficients memiliki arah negatif sebesar 2.025. Artinya, direksi wanita mempunyai arah negatif terhadap nilai M-score pada Kualitas Laporan Keuangan. Hal tersebut karena koefisien regresi direksi wanita ialah sebesar -2.025 yang mempunyai arah negatif terhadap M-score, sehingga menurunnya direksi wanita sebesar 2.025 akan meningkatkan nilai M-score dan menghasilkan M-score >-2.22. Apabila nilai mode1 beneish m-score > -2.22, maka kualitas laporan keuangan akan semakin buruk karena menggambarkan adanya unsur manipulasi dalam laporan keuangan yang disajikan perusahaan. Hal tersebut juga menunjukkan semakin meningkatnya direksi wanita maka nilai model beneish $\mathrm{m}$-score pada laporan keuangan akan menurun, artinya kualitas laporan keuangan yang disajikan oleh perusahaan dikatakan baik. Hal tersebut karena apabila nilai $\mathrm{M}$-score $\leq-2.22$, maka mencerminkan kualitas laporan keuangan yang baik karena tidak terindikasi manipulasi.

\section{Pengaruh Efektivitas Komite Audit terhadap Kualitas Laporan Keuangan}

Dapat dilihat pada Tabel 5, dapat diketahui efektivitas komite audit memiliki pengaruh yang signifikan terhadap kualitas laporan keuangan. Hal ini karena efektivitas komite audit memiliki tingkat signifikansi sebesar 0.000 di mana lebih kecil dari tingkat alpha (5\%). Selain itu, arah koefisien yang ditunjukkan pada "B" dalam Unstandardized Coefficients memiliki arah negatif yaitu sebesar -7.583. Artinya, menurunnya efektivitas komite audit maka akan meningkatkan nilai M-score sehingga mencerminkan semakin meningkatnya unsur manipulasi dalam laporan keuangan yang disajikan. Hal tersebut karena jika nilai M-Score $>-2.22$ menunjukkan bahwa dalam laporan keuangan terdapat unsur praktik manipulasi. Hal ini juga mencerminkan bahwa semakin meningkatnya efektivitas Komite Audit maka akan menurunkan nilai M-score pada kualitas laporan keuangan. Hal ini karena apabila nilai M-score $\leq-2.22$, maka kualitas laporan keuangan akan semakin baik karena menggambarkan semakin tidak adanya unsur manipulasi dalam laporan keuangan yang disajikan perusahaan.

Tabel 6. Uji Parsial (Uji t) Regresi Linier Berganda dengan Variabel Moderasi

\section{Coefficients $^{\mathrm{a}}$}

\begin{tabular}{|c|c|c|c|c|c|}
\hline \multirow[b]{2}{*}{ Model } & \multicolumn{2}{|c|}{$\begin{array}{l}\text { Unstandardized } \\
\text { Coefficients }\end{array}$} & \multirow{2}{*}{$\begin{array}{c}\text { Standardized } \\
\text { Coefficients }\end{array}$} & \multirow[b]{2}{*}{$\mathrm{t}$} & \multirow[b]{2}{*}{ Sig. } \\
\hline & $\mathrm{B}$ & Std. Error & & & \\
\hline 1 (Constant) & -.899 & .481 & & -1.868 & .062 \\
\hline DWN & -2.599 & .361 & -.231 & -7.193 & .000 \\
\hline EKA & -3.500 & .539 & -.226 & -6.490 & .000 \\
\hline DWN.EKA & -6.333 & .435 & -.530 & -5.566 & .000 \\
\hline
\end{tabular}

a. Dependent Variable: KLK

Sumber: Output Pengolahan SPSS versi 23, 2021 


\section{Pengaruh Direksi Wanita terhadap Kualitas Laporan Keuangan}

Dari hasilperhitungan yang berada pada Tabel 6 dapat diketahui bahwa direksi wanita mempunyai pengaruh signifikan. Hal tersebut karena nilai signifikansi direksi wanita sebesar 0.000 di mana lebih kecil dari tingkat alpha $(\alpha)$ yaitu sebesar 0.05 . Untuk itu, dapat disimpulkan bahwa uji signifikan pada tingkat signifikansi 5\% menyatakan bahwa hipotesis pertama $\left(\mathrm{H}_{1}\right)$ yang diajukan dalam penelitian dapat diterima. Selanjutnya, direksi wanita mempunyai koefisien regresi bertanda negatif sebesar -2.599 yang menunjukkan bahwa semakin menurunnya direksi wanita sebesar -2.599 maka akan meningkatkan nilai M-score pada kualitas laporan keuangan yang mencerminkan semakin terindikasi kecurangan pada laporan keuangan. Nilai M-Score yang > -2.22 menunjukkan bahwa masih terdapat praktik manipulasi pada laporan keuangan suatu perusahaan. Hal ini juga menggambarkan bahwa semakin meningkatnya direksi wanita maka akan menurunkan nilai M-score pada laporan keuangan. Jika nilai M-score $\leq-2.22$, maka kualitas laporan keuangan akan semakin baik karena menggambarkan tidak adanya unsur manipulasi dalam laporan keuangan yang disajikan perusahaan. Untuk itu, dapat disimpulkan bahwa direksi wanita mempunyai pengaruh negatif terhadap Kualitas Laporan Keuangan yang terdapat unsur manipulasi.

\section{Pengaruh Efektivitas Komite Audit terhadap Kualitas Laporan Keuangan}

Berdasarkan hasil perhitungan yang ditunjukkan pada Tabel 6 efektivitas komite audit mempunyai pengaruh signifikan. Hal tersebut karena nilai signifikansi sebesar 0.000 dimana nilai tersebut lebih kecil dari tingkat alpha $(\alpha)$ yaitu sebesar 0.05 . Untuk itu, dapat disimpulkan bahwa uji signifikan pada tingkat signifikansi $5 \%$ menyatakan bahwa $\mathrm{H}_{2}$ yang diajukan dalam penelitian dapat diterima. Selanjutnya, efektivitas komite audit mempunyai koefisien regresi bertanda negatif sebesar -3.500 yang menunjukkan bahwa semakin menurunnya Direksi Wanita sebesar -3.500 akan meningkatkan nilai M-score pada Kualitas Laporan Keuangan yang menunjukkan semakin buruk karena terindikasi unsur manipulasi. Apabila nilai M-score >-2.22, maka kualitas laporan keuangan akan semakin buruk karena menggambarkan adanya unsur manipulasi dalam laporan keuangan yang disajikan perusahaan. Hal ini juga menunjukkan semakin menurunnya nilai M-score sebesar -3.500 yang mencerminkan semakin meningkatnya kualitas laporan keuangan yang baik. Nilai M-Score $\leq-2.22$ menunjukkan bahwa tidak terdapat praktik manipulasi pada laporan keuangan suatu perusahaan, sehingga laporan keuangan dapat dinilai memiliki kualitas yang baik.

\section{Pengaruh Efektivitas Komite Audit yang Memoderasi Direksi Wanita terhadap Kualitas Laporan Keuangan}

Dari hasil perhitungan yang ditunjukkan pada Tabel 6 efektivitas komite audit mempunyai pengaruh signifikan. Hal tersebut karena nilai signifikansi sebesar 0.000 dimana nilai tersebut lebih kecil dari tingkat alpha $(\alpha)$ yaitu sebesar 5\%. Untuk itu, dapat disimpulkan bahwa hipotesis ketiga $\left(\mathrm{H}_{3}\right)$ yang diajukan dalam penelitian dapat diterima. Selanjutnya, direksi wanita yang dimoderasi oleh efektivitas komite audit mempunyai koefisien regresi bertanda negatif sebesar -6.333 yang menunjukkan bahwa menurunnya direksi wanita yang dimoderasi oleh efektivitas komite audit akan semakin meningkatkan nilai M-score pada kualitas laporan keuangan. Jika nilai M-score >-2.22, maka kualitas laporan keuangan akan semakin buruk karena menggambarkan adanya unsur manipulasi dalam laporan keuangan yang disajikan perusahaan. Semakin meningkat Direksi wanita yang dimoderasi oleh efektivitas komite audit akan menurunkan nilai $\mathrm{M}$-score pada kualitas laporan keuangan yang baik, karena semakin menurunnya $\mathrm{M}$-score sebesar -6.333 yang mencerminkan semakin meningkatnya kualitas laporan keuangan yang baik. Nilai model beneish m-score $\leq-2.22$ menunjukkan bahwa tidak terdapat praktik manipulasi pada laporan keuangan suatu perusahaan, sehingga laporan keuangan dapat dinilai memiliki kualitas yang baik. 
Tabel 7. Koefisien Determinasi $\left(\mathrm{R}^{2}\right)$

\begin{tabular}{|c|c|c|}
\hline Model & $R$ Square tanpa Moderasi & $R$ Square dengan Moderasi \\
\hline 1 & 0.481 & 0.647 \\
\hline
\end{tabular}

Berdasarkan Tabel 7, dapat diketahui hasil koefisiensi determinasi ntuk model regresi Direksi Wanita dan Efektivitas Komite Audit adalah sebesar 0.481. Hal tersebut menunjukkan bahwa besarnya pengaruh Direksi Wanita dan Efektivitas Komite Audit terhadap Kualitas Laporan Keuangan ialah sebesar 48,1\%, sedangkan sisanya yaitu sebesar 51,9\% dijelaskan oleh variabel-variabel lain di luar model penelitian seperti kualitas audit, board diversity, board characteristics, dan variabel lainnya yang berkaitan dengan variabel dependen.

Selanjutnya, hasil koefisien determinasi untuk model regresi direksi wanita terhadap kualitas laporan keuangan yang dimoderasi oleh efektivitas komite audit ialah sebesar 0.647. Untuk itu dapat dikatakan bahwa besarnya pengaruh Direksi Wanita terhadap Kualitas Laporan Keuangan yang dimoderasi oleh Efektivitas Komite Audit ialah sebesar 64,7\%. Apabila kedua nilai $\mathrm{R}^{2}$ (dengan dan tanpa pemoderasi) dibandingkan, dapat dikethaui bahwa nilai koefisien determinasi tanpa pemoderasi $(0.481)$ < nilai koefisiensi determinasi dengan pemoderasi (0.647). Hal tersebut menunjukkan peningkatan nilai $\mathrm{R}^{2}$ sebesar $16,6 \%$ atau $0.166(0.647$ 0.481). Untuk itu, dapat disimpulkan bahwa dengan adanya variabel pemoderasi efektivitas komite audit maka akan memperkuat pengaruh direksi wanita terhadap kualitas laporan keuangan.

\section{Kesimpulan}

Berdasarkan hasil penelitian dari pengaruh Direksi wanita terhadap kualitas laporan keuangan yang dimoderasi oleh efektivitas Komite Audit pada Perusahaan Manufaktur yang Terdaftar di Bursa Efek Indonesia (BEI) Tahun 2016-2020 maka dapat ditarik kesimpulan sebagai berikut:

1. Direksi wanita berpengaruh negatif terhadapkualitas laporan keuangan. Artinya semakin banyak direksi wanita maka akan meningkatkan kualitas laporan keuangan yang ditandai dengan semakin kecilnya nilai model Beneish M-score.

2. Efektivitas Komite Audit berpengaruh negatif terhadap kualitas laporan keuangan. Artinya semakin meningkatnya efektivitas komite audit maka akan meningkatkan kualitas laporan keuangan yang ditandai dengan semakin kecilnya nilai model Beneish M-score.

3. Efektivitas komite audit mampu memoderasi pengaruh direksi wanita terhadap kualitas laporan keuangan. Artinya, dengan pelaksanaan komite audit yang semakin efektif maka akan memperkuat pengaruh direksi wanita terhadap kualitas laporan keuangan.

\section{Acknowledge}

Penulis mengucapkan terimakasih sebanyak-banyakanya kepada pihak-pihak terkait yang telah membantu penulis dalam proses menyelesaikan penelitian ini.

\section{Daftar Pus taka}

[1] Afriyadi, Achmad Dwi. Kisruh Laporan Keuangan Garuda: Ditolak Komisaris hingga Terbukti Cacat; 2019. Available from: https://finance.detik.com/

[2] Sandria, Ferry. Ada Emiten Diduga Manipulasi Lapkeu, Langsung Dicecar BEI!; 2021. Available from: https://www.cnbcindonesia.com/

[3] Ikatan Akuntan Indonesia. Standar Akuntansi Keuangan. Jakarta: Ikatan Akuntan Indonesia; 2018.

[4] Kingsley, O.O., Adeghe, R., Gina, O. Internal control as a potential instrument for corporate governance. IOSR Journal of Economics and Finance, 2(6), 66-70; 2014.

[5] Zarkasyi, Moh. Wahyudin. Good Corporate Governance Pada Badan Usaha Manufaktur, Perbankan, dan Jasa Keuangan Lainnya. Bandung: Alfabeta; 2008.

[6] Post, C. \& Kris Byron. Women on Boards and Firm Financial Performance: A MetaAnalysis. Academy of Management Journal, Vol. 58, No. 5; 2015. 
[7] Thian, Alexander. Perilaku Organisasi. Yogyakarta: ANDI; 2021.

[8] Srinidhi, B., Gul, F.A., Tsui, J. Female directors and earnings quality. Contemporary Accounting Research, Vol. 28, pp. 1610-1644; 2011.

[9] Post, C., Rahman, N., \& Rubow, E. Green governance: Boards of directors' composition and environmental corporate social responsibility. Business \& Society, 50(1), pp. 189-223; 2011.

[10] Post, C., Rahman, N., \& Rubow, E. Green governance: Boards of directors' composition and environmental corporate social responsibility. Business \& Society, 50(1), pp. 189-223; 2011.

[11] Peraturan Otoritas Jasa Keuangan. Pembentukan dan Pedoman Pelaksanaan Kerja Komite Audit. Jakarta: Peraturan Otoritas Jasa Keuangan; 2015. Available from: https://www.ojk.go.id/id/Regulasi/Default.aspx.

[12] Hery. Auditing dan Asurans Pemeriksaan: Akuntansi Berbasis Standar Audit Internasional. Jakarta: Penerbit PT Grasindo; 2017.

[13] Abbott, L. J., Parker, S., \& Peters, G. F. Audit committee characteristics and restatements. Auditing: A Journal of Practice \& Theory, 23(1), pp. 69-87; 2004.

[14] Mouratidou, Zafeiro. Audit Committee Characteristics and Earnings Management: Evidence from Greece; 2019. 